\title{
Analisis Beberapa Sifat Kimia Tanah Terhadap Peningkatan Produksi Kelapa Sawit pada Tanah Pasir di Perkebunan Kelapa Sawit Selangkun
}

\author{
RR Darlita ${ }^{1,2}$, Benny Joy ${ }^{3}$ dan Rija Sudirja ${ }^{3}$ \\ ${ }^{1}$ PT. Citra Borneo Indah Grup, Pangkalan Bun, Kalimantan Tengah \\ ${ }^{2}$ Alumnus Program Studi Ilmu Tanah, Fakultas Pertanian, Universitas Padjadjaran \\ ${ }^{3}$ Program Studi Ilmu Tanah, Fakultas Pertanian, Universitas Padjadjaran \\ *Alamat korespondensi: darlitabuntoro@gmail.com
}

\begin{abstract}
Analyse of soil chemical properties in the encriment of oil palm production on sandy soil at Selangkun oli palm plantation
\end{abstract}

Soil is one of basic components in the development of oil palm plantation. Limitation of land causes many companies expand their areas to the sub-optimal land, such as sandy soil. This research was aimed to analyzed chemical soil properties and its relation with bunch number and bunch weight in oil palm plantation, Arut Selatan sub-district, Central Kalimantan. Survey was made in sample points that were determined based on grid system, and each sample was taken in the depth of 30 $\mathrm{cm}$. This research was descriptive and used double regression equation with backward-stepwise method. Several parameters have been analyzed, such as $\mathrm{pH}$, organic carbon, CEC, total N, total $\mathrm{P}$, $\mathrm{P}$-availability, $\mathrm{K}, \mathrm{Ca}, \mathrm{Mg}, \mathrm{Cu}, \mathrm{Zn}, \mathrm{Mn}$, and $\mathrm{B}$. The result showed that the $\mathrm{pH}$ was categorized acid, macro nutrients were medium to very low, except total $\mathrm{P}$ and $\mathrm{P}$-availability, while micro nutrients were enough, except boron which had very high amount. Furthermore, statistical analysis showed that some chemical properties, such as total N, CEC, and exchangeable $\mathrm{Al}$ were parameters which influenced production of bunch number per oil palm plant.

Keywords: Oil palm, Soil nutrient, Sandy soil

\begin{abstract}
ABSTRAK
Tanah merupakan salah satu komponen dasar dalam pembangunan perkebunan kelapa sawit. Keterbatasan lahan menyebabkan banyaknya perusahaan yang memperluas areal perkebunan ke lahan sub-optimal, seperti tanah pasir. Penelitian ini bertujuan mengkaji sifat-sifat kimia yang ada pada tanah pasir dan hubungannya dengan produksi tandan per pohon dan berat tandan rata-rata tanaman kelapa sawit di kecamatan Arut Selatan, Kalimantan Tengah. Survei dilakukan pada titik sampel didasarkan pada metode grid, dan sampel diambil pada kedalaman $30 \mathrm{~cm}$. Penelitian ini merupakan penelitian deskriptif dan menggunakan model persamaan regresi berganda metode backward-stepwise. Beberapa parameter yang dianalisis adalah pH, C-organik, KTK, N-total, Ptotal, P-tersedia, $\mathrm{K}, \mathrm{Ca}, \mathrm{Mg}, \mathrm{Cu}, \mathrm{Zn}, \mathrm{Mn}$, dan $\mathrm{B}$. Hasil analisis menunjukkan bahwa $\mathrm{pH}$ tanah tergolong rendah, kandungan hara makro berkisar sedang sampai sangat rendah, kecuali P-total dan P-tersedia, sementara kandungan hara mikronya cukup, kecuali boron yang tergolong tinggi. Sifat kimia tanah seperti N-total, KTK, dan Al-dd merupakan parameter yang meningkatkan jumlah tandan per pohon.
\end{abstract}

Kata Kunci: Kelapa sawit, Hara tanah, Tanah pasir

\section{PENDAHULUAN}

Kelapa sawit (Elaeis guineensis Jacq.) merupakan salah satu komoditas perkebunan andalan di Indonesia sebagai sumber devisa, lapangan kerja dan sumber kesejahteraan bagi petani pengusahanya. Sejak tahun 2008, minyak sawit menggeser dominasi minyak kedelai dunia dan sekaligus menempatkan minyak sawit sebagai sumber penting minyak nabati dunia. Pada tahun 
2014, minyak sawit memiliki pangsa dunia sebesar 42,1\% (GAPKI, 2014). Kebutuhan minyak sawit cenderung terus meningkat setiap tahun. Hal ini mendorong perkebunan kelapa sawit untuk terus menambah luasan areal tanam. Hingga tahun 2014, luas perkebunan kelapa sawit diperkirakan sekitar 10,9 juta ha dengan produksi Crude Palm Oil (CPO) sebesar 29,3 juta ton (BPS, 2014).

Kalimantan Tengah merupakan salah satu sentra produksi kelapa sawit di Indonesia, setelah Riau dan Sumatera Utara. Luas areal perkebunan kelapa sawit di Kalimantan Tengah seluas 1,2 juta ha dengan volume produksi mencapai 3,3 juta ton atau $11,3 \%$ terhadap total produksi nasional (BPS, 2014). Makin terbatasnya lahan sehamparan yang luas di Indonesia, membuat ruang gerak perusahaan perkebunan untuk memperluas areal semakin terbatas, sehingga perluasan perkebunan kelapa sawit mulai bergeser ke lahan-lahan sub optimal.

Tanah merupakan salah satu komponen dasar dalam pembangunan perkebunan kelapa sawit. Pemahaman mengenai karakteristik tanah di perkebunan kelapa sawit sangat diperlukan sebagai dasar dalam menentukan tindakan kultur teknis yang akan dilakukan dalam rangka menjamin kesinambungan produktivitas lahan (Rahutomo et al., 2001 dalam Firmansyah, 2014). Tanah pasir yang tergolong pada lahan sub optimal pada umumnya miskin hara dan tidak banyak dimanfaatkan sebagai media untuk kegiatan pertanian. Namun dari segi kimia tanah pasir cukup mengandung unsur kalium dan fosfor yang belum siap untuk diserap oleh tanaman sehingga hal tersebut perlu dibantu dengan proses pemupukan (Sunardi \& Sarjono, 2007). Secara fisik, tanah yang didominasi pasir akan banyak mempunyai pori makro sehingga akar mudah untuk berpenetrasi, namun semakin mudah pula air yang hilang dari tanah. Kondisi ini menjadikan tanah pasir merupakan tanah yang tidak subur, kandungan unsur hara rendah dan tidak produktif untuk pertumbuhan tanaman (Hanafiah, 2005).

Pertumbuhan dan produktivitas tanaman kelapa sawit di lahan pasir cukup beragam bergantung pada kondisi lahan dan tingkat pengelolaan yang dilakukan. Produktivitas tanaman kelapa sawit umur 5 tahun di lahan pasir 18,2 ton/ha. Sementara itu, berat tandan rata-rata (BJR) di lahan pasir pada umur 3-5 tahun adalah 6,4 $\mathrm{kg} /$ tandan. Hasil tersebut cukup baik meskipun berada di bawah produksi pada tanah mineral solum dalam.
Mengetahui potensi lahan perkebunan kelapa sawit sejak awal merupakan langkah strategis untuk menentukan tindakan kultur teknis agar produktivitas lahan tetap terjaga. Atas dasar pertimbangan yang telah diuraikan di atas maka perlu diadakan penelitian mengenai kajian hara pada tanah pasir di Kecamatan Arut Selatan, Kalimantan Tengah.

\section{BAHAN DAN METODE}

Penelitian dilakukan di perkebunan kelapa sawit (Selangkun Estate), Kecamatan Arut Selatan, Kalimantan Tengah. Daerah ini memiliki topografi datar dengan kemiringan lahan 0-3\%, curah hujan $2.218 \mathrm{~mm} /$ tahun dengan tipe iklim B yaitu basah menurut klasifikasi Schmidt-Ferguson. Secara geologi, daerah Selangkun berada pada formasi TQd yang merupakan formasi dahor berupa batu pasir dan Qs yang merupakan endapan rawa yaitu berupa lempung kaolinan dan lanau sisipan pasir. Jenis tanah di daerah ini adalah Typic Udipsamments berdasarkan Soil Taxonomy. Pada lokasi penelitian, tanaman kelapa sawit yang tumbuh merupakan tanaman yang ditanam pada tahun 2009.

Penelitian ini merupakan penelitian deskriptif menggunakan metode survei dengan mengambil sampel tanah pada masing-masing titik sampling dan dilakukan analisis kimia dan kesuburan tanah di laboratorium. Satu blok lokasi sampling tanah pasir dipilih kemudian ditentukan 30 (tiga puluh) titik sampel menggunakan sistem grid yang dari setiap titik sampelnya diambil sampel tanah secara komposit dari kedalaman 0-30 cm. Selanjutnya, contoh tanah terganggu diambil secara komposit dari kedalaman 0-30 cm di tiga puluh titik sampel untuk setiap jenis tanah. Parameter hara tanah dan metode analisis yang digunakan adalah $\mathrm{C}$ organik (Walkley and Black), N-total (Kjehdahl), Ptotal (Bray), P-tersedia (Bray II), K (Flamephotometry), Ca dan Mg (AAS), KTK (Destilasi, Ammonium asetat pada $\mathrm{pH} 7$ ), Fe dan $\mathrm{Cu}$ (AAS) B (Spectrophotometry), $\mathrm{pH}$ ( $\mathrm{pH}$ meter), serta data penunjang yaitu tekstur tanah (pipet). Hasil analisis tersebut untuk kemudian dibandingkan dengan standar kesuburan tanah yang dikeluarkan PPKS (1997) untuk mengetahui apakah kadar hara dalam tanah sangat rendah, rendah, sedang, tinggi atau sangat tinggi.

Untuk melihat hubungan antara sifat kimia tanah dengan produksi tandan per tanaman dan BJR dibuat suatu model persamaan regresi berganda 
metode backward-stepwise. Selanjutnya untuk mengkaji sumbangan sifat kimia tanah secara bersama-sama dalam menentukan BJR dan produksi tandan per tanaman kelapa sawit dilakukan analisis regresi berganda dalam bentuk persamaan linier.

\section{HASIL DAN PEMBAHASAN}

\section{Karakteristik tanah}

Lokasi penelitian yang berupa lahan pasir di Selangkun berada pada formasi geologi TQd yang merupakan formasi dahor terdiri dari fragmen kuarsit dan basal (Sutisna dkk., 1996) dan Qs yang merupakan endapan rawa berupa lempung kaolinan dan lanau sisipan pasir. Berdasarkan hasil identifikasi mineral pasir yang dilakukan Utomo dkk. (1997), pasir di dataran Palangkaraya, Kalimantan Tengah mengandung mineral kuarsa, feldspar (ortoklas, mikrolin dan sanidin), mika (muskovit dan biotit) dan amfibol. Mineral kuarsa $\left(\mathrm{SiO}_{2}\right)$ tergolong mineral yang tahan terhadap pelapukan dan miskin hara (Goldich, 1938). Pelapukan mineral feldspar dan mika diharapkan menyumbang hara K (Churchman \& Lowe, 2012), sedangkan pelapukan amfibol merupakan sumber dari hara $\mathrm{Ca}, \mathrm{Mg}$, dan Fe. (Mohr et. al., 1972 dalam Suharta, 2010; Churchman \& Lowe, 2012).

Berdasarkan Kunci Taksonomi Tanah USDA, tanah pasir di lokasi penelitian termasuk dalam klasifikasi Typic Udipsamment. Dalam sistem penamaan tanah FAO, tanah ini tergolong podsol yang terbentuk melalui proses podsolisasi. Menurut (Driessen \& Dudal, 1991), podsol di wilayah tropika dijumpai pada batuan induk batu pasir dan pasir kuarsitik. Di wilayah tropika basah seperti di lokasi penelitian, podsolisasi terjadi sangat kuat sehingga horison pencucian sangat tebal di atas lapisan spodik yang ditandai dengan warna kelabu pucat di antara lapisan berwarna kelam dan spodik yang gelap. Hasil analisis menunjukkan tanah di lokasi penelitian mengandung pasir $85,75 \%$, debu $5,97 \%$, dan liat $8,28 \%$ dengan demikian tekstur tanahnya yaitu pasir berlempung.

\section{Kandungan hara}

Kandungan hara pada tanah pasir dapat dilihat pada Tabel 1. Hasil analisis menunjukkan bahwa tanah di lokasi penelitian memiliki pH 3,95 dan tergolong sangat rendah. Rendahnya $\mathrm{pH}$ ini disebabkan oleh tercucinya kation-kation basa yang terjadi dari lapisan atas ke lapisan lebih dalam akan meninggalkan kation-kation $\mathrm{H}^{+}$dan $\mathrm{Al}^{3+}$ di lapisan atas yang sangat berperan dalam kemasaman tanah (Hong, 2008). Rendahnya pH tanah akan menyebabkan menurunnya ketersediaan hara bagi tanaman yang pada akhirnya akan menurunkan produksi Tandan Buah Segar (TBS). Soewandita (2008) dalam penelitiannya menunjukkan bahwa status hara gambut di Kabupaten Bengkalis untuk dilakukan budidaya secara umum terkendala oleh karakteristik $\mathrm{pH}$ tanahnya yang tergolong masam hingga sangat masam. Penambahan bahan organik meningkatkan $\mathrm{pH}$ tanah dan pada saat yang sama mengurangi Al-dd dan Fe-dd (Ch'Ng et al., 2014). Bahan organik tanah dianggap sebagai elektron donor yang menyumbang reaksi reduksi logamlogam pada $\mathrm{pH}$ rendah (Olafisoye et al., 2016).

Kandungan C-organik di lokasi penelitian adalah 2,75\% dan tergolong sedang. Pada umumnya tanah pasir memiliki kandungan C-organik yang rendah. Aplikasi penambahan bahan organik yang berasal dari tandan kosong kelapa sawit dengan dosis 40 ton/ha paling sedikit sekali dalam setahun diduga berkontribusi terhadap kandungan C-organik di tanah pasir. Secara umum, bahan organik tanah memiliki peranan yang penting dalam siklus karbon dan hara dan perubahan $\mathrm{pH}$ tanah (Wang et al., 2013).

Kandungan N-total di lokasi penelitian tergolong rendah dengan nilai $0,1 \%$ meskipun $\mathrm{C}$ organik pada tanah pasir, yang merupakan sumber utama $\mathrm{N}$, tergolong sedang dan adanya aplikasi pupuk urea selama 5 tahun terakhir dengan dosis sekitar 1,5-2 kg/tanaman/tahun. Rendahnya N diduga karena $\mathrm{N}$ hilang dengan mudah melalui pencucian atau penguapan. Dengan tekstur tanah yang didominasi pasir di mana jenis tanah ini memiliki tingkat porositas yang tinggi, pencucian dan penguapan akan berlangsung dengan cepat.

Kandungan P-total tanah di lokasi penelitian tergolong sangat tinggi dengan nilai 50,91 ppm. Sementara kandungan P-tersedia yaitu 17,83 dan juga tergolong sangat tinggi. Aplikasi Rock Phosphate (RP) diduga memengaruhi tingginya kandungan P-total tanah. Dosis pupuk RP yang diaplikasikan sejak tahun 2013 berkisar antara 1,75$2 \mathrm{~kg} /$ tanaman/tahun. Perbedaan kandungan antara P-total dan P-tersedia diduga karena fosfor cenderung bereaksi dengan komponen tanah membentuk senyawa yang relatif tidak larut sehingga tidak tersedia bagi tanaman (Joy, 2006). Fiksasi fosfat misalnya, merupakan salah satu kendala kesuburan tanah pada tanah-tanah yang mineralnya dipengaruhi oleh muatan variabel. 
Selain itu, tekstur tanah yang didominasi pasir menyebabkan P mudah tercuci ke lapisan bawah.

Tabel 1. Kandungan hara pada tanah pasir dan klasifikasinya

\begin{tabular}{|c|c|c|c|}
\hline \multirow{2}{*}{ Sifat tanah } & \multirow{2}{*}{ Satuan } & \multicolumn{2}{|c|}{$\begin{array}{c}\text { Kandungan hara dalam } \\
\text { tanah }\end{array}$} \\
\hline & & Nilai & Klasifikasi \\
\hline $\mathrm{pH}$ & & 3,95 & $\begin{array}{c}\text { Sangat } \\
\text { Rendah }^{1}\end{array}$ \\
\hline Al-dd & $\mathrm{cmol} / \mathrm{kg}$ & 0,23 & - \\
\hline H-dd & $\mathrm{cmol} / \mathrm{kg}$ & 2,30 & - \\
\hline $\mathrm{C}-$ & & & \\
\hline Organik & $\%$ & 275 & Sedang $^{1}$ \\
\hline N Total & $\%$ & 0,1 & Rendah $^{1}$ \\
\hline P-Total & ppm & 50,91 & Sangat tinggi ${ }^{1}$ \\
\hline P-tersedia & ppm & 17,83 & Sangat tinggi ${ }^{1}$ \\
\hline KTK & $\mathrm{cmol} / \mathrm{kg}$ & 9,44 & Rendah $^{1}$ \\
\hline K & $\mathrm{cmol} / \mathrm{kg}$ & 0,2 & $\begin{array}{c}\text { Rendah }^{1} \\
\text { Sangat }\end{array}$ \\
\hline $\mathrm{Ca}$ & $\mathrm{cmol} / \mathrm{kg}$ & 0,8 & $\begin{array}{c}\text { Rendah }^{1} \\
\text { Sangat }\end{array}$ \\
\hline $\mathrm{Mg}$ & $\mathrm{cmol} / \mathrm{kg}$ & 0,28 & Rendah $^{1}$ \\
\hline $\mathrm{Na}$ & $\mathrm{cmol} / \mathrm{kg}$ & 0,13 & Rendah \\
\hline $\mathrm{Cu}$ & ppm & 3,63 & Cukup ${ }^{2}$ \\
\hline $\mathrm{Zn}$ & ppm & 4,77 & Cukup $^{2}$ \\
\hline $\mathrm{Fe}$ & ppm & 91,58 & Cukup \\
\hline $\mathrm{Mn}$ & ppm & 5,24 & Cukup $^{2}$ \\
\hline B & $\mathrm{ppm}$ & 7,16 & Sangat tinggi $^{3}$ \\
\hline $\begin{array}{l}{ }^{1} \text { Klasifikasi ber } \\
\text { dikeluarkan ole } \\
{ }^{2} \text { Klasifikasi ber } \\
\text { dikeluarkan ole } \\
{ }^{3} \text { Klasifikasi } \\
\text { dikeluarkan ole }\end{array}$ & $\begin{array}{l}\text { sarkan stanc } \\
\text { PPKS (1997 } \\
\text { asarkan stan } \\
\text { Balai Penel } \\
\text { perdasarkan } \\
\text { Kelling (19S }\end{array}$ & $\begin{array}{l}\text { kesuburan } \\
\text { kesuburar } \\
\text { Tanah (2 } \\
\text { indar ke }\end{array}$ & $\begin{array}{l}\text { ah yang } \\
\text { ah yang } \\
\text { aran tanah yang }\end{array}$ \\
\hline
\end{tabular}

Kapasitas Tukar Kation (KTK) di lokasi penelitian tergolong rendah dengan nilai 9,44 $\mathrm{cmol} / \mathrm{kg}$ namun masih di atas rata-rata KTK tanah pasir pada umunya 2-4 cmol/kg (Ashari, 1995). Faktor-faktor yang dapat meningkatkan KTK didasarkan pada jumlah liat dan bahan organik. Rendahnya kandungan liat (8,28\%) menyebakan rendahnya KTK. Namun demikian, nilai KTK yang di atas rata-rata tersebut diduga berasal dari sumbangan bahan organik yang diaplikasikan dengan dosis 40 ton/ha.

Berdasarkan hasil analisis laboratorium kandungan $\mathrm{K}, \mathrm{Ca}$, dan $\mathrm{Mg}$ pada tanah pasir berturutturut yaitu $0,2,0,8$, dan $0,28 \mathrm{cmol} / \mathrm{kg}$. Kandungan $\mathrm{K}$ tergolong rendah, sementara $\mathrm{Ca}$ dan $\mathrm{Mg}$ tergolong sangat rendah. Rendahnya kation-kation basa disebabkan oleh curah hujan yang tinggi, >2000 $\mathrm{mm} /$ tahun, sehingga kation basa tersebut mudah tercuci (Chadwick et al., 2003). Selain itu, rendahnya $\mathrm{pH}$ tanah yang menyebabkan kation asam seperti Al bersifat mobile. Penelitian sebelumnya membuktikan bahwa terdapat korelasi yang signifikan antara phytotoxic Al dengan $\mathrm{pH}$ yang rendah dan hal ini berhubungan dengan berkurangnya kation basa dapat dipertukarkan dalam larutan tanah (Rout et al., 2001). Rendahnya kation-kation basa ini dapat menghambat pertumbuhan yang optimum pada kelapa sawit. Berdasarkan hasil penelitian yang dilakukan oleh Ginting dkk. (2013), kisaran nilai rasio hara yang seimbang untuk tanaman kelapa sawit masingmasing 5,6-10,1 untuk $\mathrm{Ca} / \mathrm{K}, 2,1-2,5$ untuk $\mathrm{Ca} / \mathrm{Mg}$ dan 2,1-4,5 untuk Mg/K. (Corley \& Tinker, 2003) menyebutkan perimbangan $\mathrm{K}: \mathrm{Ca}: \mathrm{Mg}$ di tanah yang optimum untuk budidaya kelapa sawit adalah 10:60:30. Pada penelitian ini hasil perimbangan $\mathrm{K}: \mathrm{Ca}: \mathrm{Mg}$ pada tanah pasir yaitu 15,56:62,86:21,58.

Berdasarkan kriteria kesuburan tanah menurut Balai Penelitian Tanah (2009), kisaran unsur hara $\mathrm{Cu}$ pada tanah pasir tergolong cukup dengan nilai 3,63 ppm. Pada banyak studi, $\mathrm{Cu}$ biasanya menunjukkan gejala defisiensi pada tanah pasir namun tidak pada studi ini. Hal ini diduga disebabkan pada setiap pemupukan, unsur mikro menjadi bagian dari pupuk komersial. Aplikasi pupuk ZinCop pada tanah pasir dimulai sejak tahun 2014 dengan dosis $0,10 \mathrm{~kg} /$ tanaman/tahun. $\mathrm{Cu}$ merupakan unsur mikro yang terlibat langsung dalam proses metabolisme sel dan aktivitas enzim sebagai kofaktor enzim.

Kandungan Zn di lokasi penelitian tergolong cukup dengan nilai 4,77 ppm. Kandungan Zn pada jenis tanah ini lebih rendah dibandingkan kandungan Zn pada tanah di Malaysia, yaitu sekitar 95 ppm (Zarcinas et al., 2004). Batas maksimum diperbolehkannya kandungan $\mathrm{Zn}$ dalam tanah adalah 90 ppm (Olafisoye et al., 2016). Kandungan Zn dalam tanah dapat berasal dari bahan induk, dekomposisi bahan organik, dan pupuk, pengotor pada pupuk RP yang sudah diaplikasikan selama empat tahun.

Hasil penelitian menunjukkan kandungan Mn pada tanah pasir tergolong cukup dengan nilai 5,24 ppm. Kelarutan Mn dipengaruhi oleh potensial redoks dan $\mathrm{pH}$ tanah. Semakin tinggi $\mathrm{pH}$, semakin rendah tingkat kelarutannya. Mangan diperlukan tanaman sebagai aktivator enzim respirasi dalam reaksi metabolisme nitrogen dan fotosintesa. Mn juga diperlukan untuk mengaktifkan nitrat 
reduktase sehingga tanaman yang mengalami kekurangan, serta menyediakan oksigen untuk selsel di mitokondria (Olafisoye et al., 2016).

Kandungan boron di lokasi penelitian tergolong sangat tinggi dengan nilai 7,16 ppm. Sumber boron dapat berasal dari bahan organik, batuan beku seperti batuan kapur, batu pasir, dan batu liat, serta pemupukan sementara ketersediannya dipengaruhi oleh tekstur tanah, macam lempung, $\mathrm{pH}, \mathrm{Al}$ dan $\mathrm{Fe}$ hidroksida, dan susunan ion dalam tanah. Tingginya kandungan boron dapat berasal dari aplikasi pupuk borat di lokasi penelitian telah dilakukan sejak tahun 2013 dengan dosis 0,05-0,18 kg/tanaman/tahun. Mathew et al. (2013) dalam penelitiannya di tanah pasir menyebutkan bahwa untuk meningkatkan ketersediaan boron pada tanah supaya sesuai dengan pertumbuhan tanaman diperlukan aplikasi boron sebesar 2,5 kg/ha. Boron berperan dalam peningkatan viabilitas polen pada tanaman kelapa sawit.

\section{Hubungan antara sifat kimia tanah dengan produksi} rata-rata tandan per pohon dan berat tandan rata-rata Pada tanah pasir, pengaruh sifat-sifat kimia tanah terhadap produksi tandan per pohon memenuhi persamaan regresi:

$\mathrm{Y}=3,764+8,372$ Al_dd $-18,49$ N_total + 0,255 KTK

Dari hasil regresi berganda diketahui bahwa sifat kimia tanah yang paling berpengaruh terhadap produksi tandan per pohon pada tanah pasir adalah $\mathrm{N}$-total dengan nilai $\beta=0,584$. Pada dasarnya $\mathrm{N}$ merupakan unsur yang sangat berperan pada proses vegetatif tanaman dapat meningkatkan produksi klorofil sehingga luas permukaan daun semakin meningkat. N-total dalam tanah pasir tergolong rendah tetapi dapat menurunkan produksi tandan per pohon karena dapat menghambat proses generatif pada tanaman. Selain itu, aplikasi pupuk N yang tinggi dapat menurunkan $\mathrm{pH}$ tanah sehingga dapat berpengaruh terhadap serapan basa-basa. Faktor lainnya yang berpengaruh adalah KTK. Peningkatan KTK dapat menaikkan produksi tandan per pohon disebabkan tingginya bahan organik yang berkontribusi terhadap meningkatnya muatan negatif (Olafisoye et al., 2016). Dengan meningkatnya muatan negatif maka potensinya untuk mengikat unsur hara yang sebagian besar merupakan kation positif akan meningkat. Dalam persamaan di atas Al-dd juga berpengaruh nyata terhadap produksi tandan dengan hubungan yang positif. Hal ini diduga karena kandungan Al_dd pada tanah pasir di lokasi penelitian rendah yang disebabkan tingginya tingkat pencucian, sehingga penambahan Al_dd masih akan berpengaruh positif terhadap produksi tandan per pohon. Dari hasil regresi berganda metode diketahui bahwa tidak ada sifat kimia tanah yang berpengaruh nyata terhadap BJR pada tanah pasir.

\section{SIMPULAN}

1. Kandungan hara makro pada tanah pasir pada umumnya rendah dan sangat rendah, kecuali Ptotal dan P-tersedia, sementara hara mikro tergolong cukup kecuali boron.

2. Unsur-unsur yang berpengaruh terhadap jumlah tandan per pohon adalah N-total, Al-dd, dan KTK. N-total paling berpengaruh dengan hubungan yang negatif karena tingginya $\mathrm{N}$ dapat menghambat proses generatif pada tanaman.

\section{UCAPAN TERIMAKASIH}

Penelitian ini terlaksana atas dukungan PT. Citra Borneo Indah Grup. Terima kasih kepada Direktur Utama, Direktur HRD dan seluruh manajemen perusahaan.

\section{DAFTAR PUSTAKA}

Ashari, S. 1995. Hortikultura Aspek Budidaya. Universitas Indonesia. Jakarta.

BPS. 2014. Statistik Kelapa Sawit Indonesia. Badan Pusat Statistik Indonesia. Jakarta.

Balai Penelitian Tanah. 2009. Petunjuk Teknis Analisis Kimia Tanah, Tanaman, Air dan Pupuk. Balai Penelitian Tanah. Bogor.

Ch'Ng, HY, OH Ahmed, and NMA Majid. 2014. Improving phosphorus availability in an acid soil using organic amendments produced from agroindustrial wastes. Sci. World J. DOI:10.1155/2014/506356.

Chadwick, OA, RT Gavenda, EF Kelly, K Ziegler, CG Olson, W Crawford Elliott, and DM Hendricks. 2003. The impact of climate on the biogeochemical functioning of volcanic soils. Chem. Geol. 202(3-4): 195-223.

Churchman, $\mathrm{Gj}$ and $\mathrm{D}$ Lowe. 2012. Alteration, formation, and occurrence of minerals in soils. Handb. Soil Sci. Prop. Process. 1: 2072. 
Corley, RHV and PB Tinker. 2003. The Oil Palm, Fourth Edition. Blackwell Publishing Company. Iowa.

Driessen, PM and R Dudal. 1991. The Major Soils of the World. Wageningen Agricultural University.

Firmansyah, M.A. 2014. Karakterisasi , Kesesuaian Lahan dan Teknologi Kelapa Sawit Rakyat di Rawa Pasang Surut Kalimantan Tengah Characteristic of Land Suitability and Farmer Oil Palm Technology in Tidal Swamp of Central Kalimantan. 14(2): 97105.

GAPKI. 2014. Industri Minyak Sawit Indonesia Menuju 100 Tahun NKRI. Membangun Kemandirian Ekonomi, Energi dan Pangan Secara Berkelanjutan. Gabungan Pengusaha Kelapa Sawit Indonesia.

Ginting, EN, A Sutandi, B Nugroho, dan T Indriyati. 2013. Rasio dan kejenuhan hara $\mathrm{K}, \mathrm{Ca}, \mathrm{Mg}$ di dalam tanah untuk tanaman kelapa sawit (Elaeis guineensis Jacq). J. Tanah dan Lingkungan. 15(2): 60-65.

Goldich, S. 1938. A Study in Rock-Weathering. J. Geol. 46(1): 17-58.

Hanafiah, KA. 2005. Dasar-Dasar Ilmu Tanah. Raja Grafindo Persada. Jakarta.

Hong, TK. 2008. Principles of Soil Chemistry. $2^{\text {nd }}$ Ed. Marse, Dekker Inc. New York.

Joy, B. 2006. Unsur Hara Fosfor, Ketersediaan dan Permasalahannya di dalam Tanah. Sekolah Tinggi Tekstil Bandung, Bandung.

Mathew, J, G Sumam, and M Indira. 2013. Effect of sulphur and boron on the performance of sesame (Sesamum indicum L.) in Onattukara sandy soil of Kerala, India. Indian J. Agric. Res. 47(3): 214-219.

Olafisoye, BO, OO Oguntibeju, and OA Osibote. 2016. An assessment of the bioavailability of metals in soils on oil palm plantations in Nigeria. Pol. J. Environ. Stud. 25(3): 11251140 .
PPKS. 1997. Gejala Defisiensi Hara dan Kelainan pada Tanaman Kelapa Sawit. Pusat Penelitian Kelapa Sawit, Medan.

Rout, GR, S Samantaray, and P Das. 2001. Aluminium toxicity in plants: A review. Agronomie. 21(1): 3-21.

Soewandita, H. 2008. Studi kesuburan tanah dan analisis kesesuaian lahan untuk komoditas tanaman perkebunan di Kabupaten Bengkalis. J. Sains dan Teknol. Indones. 10(2): 128-133.

Suharta, N. 2010. Karakteristik dan permasalahan tanah marginal dari batuan sedimen masam di Kalimantan. J. Litbang Pertan. 29(98): 139-146.

Sunardi, dan Y Sarjono. 2007. Penentuan kandungan unsur makro pada lahan pasir pantai Samas Bantul dengan Metode Analisis Aktivasi Neutron (AAN). Prosiding PPI-PDIPTNPustek Akselerator dan Proses BahanBATAN. Yogyakarta. Juli 2007.

Sutisna, T, IZ Gondhonegoro, B Suyekti, dan E Rifai. 1996. Inventarisasi dan evaluasi mineral non logam di Kabupaten Seruyan dan Kotawaringin Timur, Kalimantan Tengah. Prosiding Pemaparan Hasil-hasil Kegiatan Lapangan dan Non Lapangan, Pusat Sumberdaya Geologi.

Utomo, S, R Sutanto, dan A Maas. 1997. Karakteristik kimiawi dan genesis tanah podsol di dataran Palangkaraya, Kalimantan Tengah. J. Ilmu Tanah dan Lingkungan. 1(1): 11-18.

Wang, Y, C Tang, J Wu, X Liu, and J Xu. 2013. Impact of organic matter addition on $\mathrm{pH}$ change of paddy soils. J. Soils Sediments. 13(1): 12-23.

Zarcinas, BA, P Pongsakul, MJ Mclaughlin, and G Cozens. 2004. Heavy metals in soils and crops in Southeast Asia. Environ. Geochem. Health. 26(4): 359-371. 